ALCHEMY Jurnal Penelitian Kimia

Laman resmi: https://jurnal.uns.ac.id/alchemy

\title{
Prakonsentrasi Ion Cd(II) dalam Sampel Pupuk Nitrogen, Fosfor dan Kalium (NPK) Menggunakan Alumina Teraktivasi sebagai Material Pengisi Kolom
}

\author{
Lossi Hotmaida Simanjuntak $^{\mathrm{a}, \mathrm{b}}$, Erwin Erwin ${ }^{\mathrm{a}}$, Aman Sentosa Panggabean ${ }^{\mathrm{a}}{ }^{*}$ \\ ${ }^{a}$ Program Studi Kimia, FMIPA, Universitas Mulawarman Jl. Barong Tongkok Kampus Gn. Kelua, Samarinda, 75119 \\ bepartemen Laboratorium Quality Control PT. Pupuk Kalimantan Timur, Bontang, 75313 \\ *Corresponding author: amanspanggabean@yahoo.com \\ DOI: 10.20961/alchemy.16.2.39363.152-162
}

Received 22 January 2020, Accepted 17 July 2020, Published 01 September 2020

\section{Kata kunci: \\ alumina; \\ Cd(II); \\ kolom; \\ prakonsentrasi;}

SSA.

\section{Keywords:}

alumina;

Cd(II);

column;

preconcentration;

AAS.
ABSTRAK. Prakonsentrasi ion Cd(II) dalam sampel pupuk nitrogen, fosfor dan kalium (NPK) menggunakan alumina teraktivasi sebagai material pengisi kolom telah dilakukan. Alumina terlebih dahulu diaktivasi dengan $\mathrm{NaOH}$ pada $\mathrm{pH} 8$ sebelum dimasukkan ke dalam kolom. Beberapa parameter penting dalam tahapan prakonsentrasi yang dapat meningkatkan kinerja analitik pengukuran telah ditentukan menggunakan instrumen spektrofotometer serapan atom (SSA). Hasil penelitian menunjukkan kondisi optimum tahapan prakonsentrasi ion Cd(II), adalah pada volume sampel $10 \mathrm{~mL}$, volume $\mathrm{HNO}_{3}$ adalah $4 \mathrm{~mL}$ pada konsentrasi $0,5 \mathrm{M}$, dengan nilai kapasitas retensi adalah 1,4113 $\mathrm{mg} \mathrm{Cd}(\mathrm{II}) / \mathrm{g}$ alumina. Kinerja analitik pengukuran metode sangat baik, ditunjukkan dengan nilai batas deteksi metode adalah $2,7997 \mu \mathrm{g} / \mathrm{L}$. Presisi metode dinyatakan sebagai persentase koefisien variansi adalah 4,03\%. Penggunaan alumina sebagai bahan pengisi kolom dapat meningkatkan signal sebesar 2,5 kali dibandingkan dengan pengukuran ion $\mathrm{Cd}(\mathrm{II})$ secara langsung. Akurasi metode ini sangat baik, dengan nilai persen perolehan kembali adalah 91,67 - 103,49\%, menunjukkan bahwa matriks sampel tidak mempengaruhi hasil pengukuran, sehingga metode ini dapat digunakan untuk analisis ion $\mathrm{Cd}(\mathrm{II})$ dalam sampel pupuk NPK. Estimasi ketidakpastian metode ini juga telah dihitung dan ditunjukkan dengan nilai persen ketidakpastian adalah $14,16 \%$.

\begin{abstract}
Preconcentration of Cd(II) Ion in Nitrogen, Phosphor, and Kalium (NPK) Fertilizer Sample Using Activated Alumina as a Column Filler Material. The research about preconcentration of $\mathrm{Cd}(\mathrm{II})$ in NPK fertilizer using activated alumina as a column filler material was done. The column used a filler material of alumina previously activated using $\mathrm{NaOH}$ at $\mathrm{pH}$ 8. Some important parameters in the preconcentration stage are able to increase the analytical performance, determined using atomic absorption spectrophotometer (AAS). The result of the research shows the optimum condition of preconcentration stage $\mathrm{Cd}(\mathrm{II})$ ion are volume of the sample was $10 \mathrm{~mL}$, the volume of eluent $\mathrm{HNO}_{3}$ was 4 $\mathrm{mL}$ with a concentration of $0.5 \mathrm{M}$, with the retention of capacity value was $1.4113 \mathrm{mg} \mathrm{Cd}(\mathrm{II}) / \mathrm{g}$ alumina. The analytical performance of this method is good, shown with the limit of detection value was $2.7997 \mu \mathrm{g} / \mathrm{L}$. The precision of this method was indicated by the percentage of the coefficient variance of $4.03 \%$. Alumina used as a filler column can increase the signal up to 2.5 times for direct $\mathrm{Cd}(\mathrm{II})$ ions measurement. The accuracy of this method is excellent, with the recovery percentage value was $91.67-103.49 \%$, indicating that the matrices of NPK fertilizer give no effect on the results of measurements, and this method was capable of analyzing Cd(II) ions in NPK fertilizer. The uncertainty of this method was estimated as the percentage of the uncertainty of $14.16 \%$.
\end{abstract}

\section{PENDAHULUAN}

Logam berat yang terdistribusi di alam dapat dengan mudah memasuki rantai makanan dan terakumulasi dalam tubuh makhluk hidup, karena sifatnya yang nonbiodegradable. Salah satu logam berat yang ada di alam adalah cadmium $(\mathrm{Cd})$, yang memiliki sifat beracun bagi makhluk hidup. Dalam tubuh manusia, Cd akan terakumulasi di hati dengan mengikat gugus sufhidril (-SH) dalam enzim, sehingga dapat merusak kerja enzim yang menyebabkan kerusakan jantung, hati, ginjal paru-paru dan mutagenesis (Pourreza et al., 2014). Pada tanaman akumulasi Cd akan menyebabkan gangguan pertumbuhan hingga mempercepat kematian tanaman (Sutrisno and Kuntyastuti, 2015). Karena sifatnya yang beracun, Cd menjadi parameter kontaminan yang dipersyaratkan dalam baku mutu lingkungan maupun produk pertanian.

Salah satu sumber kontaminasi Cd pada tanaman adalah penggunaan pupuk kimia yang berlebihan. Oleh sebab itu penentuan kandungan Cd dalam pupuk kimia wajib dilakukan (Sutrisno and Kuntyastuti, 2015). Salah satu pupuk kimia yang banyak digunakan oleh petani di Indonesia adalah pupuk NPK yang merupakan pupuk 
majemuk dengan komponen utama nitrogen (N), fosfor (P) dan kalium (K) (SNI, 2012). Bahan baku pembuatan pupuk NPK adalah urea, diamonium fosfat atau monosodium fosfat dan kalium klorida sebagai sumber nitrogen, fosfor dan kalium. Diamonium fosfat, monosodium fosfat dan kalium klorida merupakan senyawa yang secara alami terdapat di alam. Bahan baku tersebutlah yang menjadi bahan pembawa atau sumber kontaminan $\mathrm{Cd}$ dan logam berat lainnya dalam pupuk NPK (Mardiani, 2008).

Kandungan ion Cd dalam pupuk NPK sangat kecil begitu pula keberadaan ion Cd di alam, sehingga dibutuhkan metode yang sangat sensitif untuk menetapkan konsentrasi $\mathrm{Cd}$ dalam berbagai sampel. Metode uji yang umum digunakan untuk menetapkan konsentrasi $\mathrm{Cd}$ adalah Flame Atomic Absorption Spectrometry (FAAS) (Han et al., 2011), Inductively Coupled Plasma-Optical Emission Spectroscopy (ICP-OES) (Pirdaus et al., 2018), Inductively Coupled Plasma-Mass Spectrometry (ICP-MS) (Perkovic et al., 2017). Faktor efek matriks pupuk NPK saat pembentukan plasma dalam sistem ICP sangat mengganggu, sehingga penentuan Cd dalam sampel pupuk tidak dapat dilakukan secara maksimal (Pirdaus et al., 2018). Penentuan Cd dalam pupuk NPK secara langsung dengan FAAS, juga sulit diterapkan karena kandungan Cd yang sangat kecil dan adanya efek matriks dalam sampel. Oleh karena itu, diperlukan suatu teknik prakonsentrasi atau pemekatan yang sekaligus dapat menyederhanakan matriks dalam sampel. Teknik prakonsentrasi menjadi salah satu solusi dalam penentuan logam berat dalam tingkat runut (trace), karena selain dapat meningkatkan limit deteksi, teknik prakonsentrasi juga dapat meminimalkan efek matriks dalam sampel (Miro and Frenzel, 2014; Panggabean et al., 2015; Suwarsa et al., 2007).

Prakonsentrasi ion Cd dalam berbagai sampel dengan menggunakan resin atau absorben sebagai material pengisi kolom telah banyak dilakukan, diantaranya penggunaan nano- $\mathrm{TiO}_{2}$ termodifikasi dengan 2mercaptobenzothiazole (Pourreza et al., 2014), (2-pyridylazo) 2-naphtol (PSDVB-PAN) (Amran et al., 2011), mikroorganisme Streptomyces albus (Yildiz et al., 2013), amberlite XAD-4 (Ozdemir, 2016), nano karbon termodifikasi (Gouda and Zordok, 2018) dan silika gel (Xu et al., 2013). Juga telah dikembangkan teknik prakonsentrasi Cd dalam sampel air sungai menggunakan metode ekstraksi kembali (Koesmawati et al., 2017).

Pada penelitian ini telah dikembangkan teknik prakonsentrasi $\mathrm{Cd}$ (II) menggunakan alumina teraktivasi berbasis kolom dengan menggunakan instrumen SSA. Alumina dilaporkan telah digunakan sebagai material pengisi kolom dalam tahapan prakonsentrasi $\mathrm{Cr}(\mathrm{VI})$, tetapi belum pernah dilakukan untuk prakonsentrasi $\mathrm{Cd}(\mathrm{II})$ dalam sampel pupuk NPK. Alumina dalam kolom diaktivasi dengan larutan asam atau basa, dengan mencari jenis asam atau basa yang tepat dan jenis eluen yang tepat. Aktivasi ini perlu dilakukan untuk lebih mengoptimalkan dan meningkatkan jumlah kapasitas retensi alumina tersebut. Hasil eluat dari kolom diukur absorbansinya menggunakan instrumen SSA. Untuk memperoleh hasil pengukuran yang valid, telah dilakukan penentuan beberapa optimasi pengukuran yaitu $\mathrm{pH}$ optimal, jenis eluen optimal, konsentrasi eluen optimal, volume eluen optimal, volume sampel optimal dan kapasitas serapan alumina. Kinerja analitik dari teknik prakonsentrasi yang dikembangkan juga telah diuji, yang meliputi penentuan daerah rentang linear pengukuran, akurasi, presisi, batas deteksi, dan aplikasi metode ini penentuan Cd dalam pupuk NPK. Penelitian ini juga dilengkapi dengan estimasi ketidakpastian pengukuran yang ditambahkan dalam pelaporan hasil uji.

\section{METODE PENELITIAN}

Alat-alat yang digunakan dalam penelitian ini adalah SSA Shimadzu AA-700, seperangkat unit komputer, pH meter Hach HQ-11d, neraca analitik digital Mettler Toledo, peralatan gelas standar laboratorium, kertas saring Whatman 40, bulb dan kolom gelas dengan diameter $1 \mathrm{~cm}$ dan panjang $15 \mathrm{~cm}$.

Bahan-bahan yang digunakan dalam penelitian ini adalah larutan CRM Cd $987 \mathrm{mg} / \mathrm{L}$ (E’Merck), $\mathrm{Cd}\left(\mathrm{NO}_{3}\right)_{2}$, alumina berukuran $50-200 \mu \mathrm{m}\left(70-290\right.$ mesh), $\mathrm{H}_{2} \mathrm{SO}_{4}, \mathrm{NaOH}, \mathrm{HNO}_{3}, \mathrm{HCl}, \mathrm{CH}_{3} \mathrm{COOH}, \mathrm{H}_{3} \mathrm{BO}_{3}$, dengan kualitas pro analysis (p.a.) (E’Merck), aquabides, dan sampel pupuk NPK dari PT. Pupuk Kalimantan Timur.

\section{Aktivasi Alumina}

Untuk memperoleh hasil penyerapan (retensi) yang maksimal terhadap ion $\mathrm{Cd}(\mathrm{II})$, sehingga dapat digunakan sebagai material pengisi kolom dalam tahapan prakonsentrasi Cd(II) dalam sampel pupuk NPK, resin alumina perlu diaktivasi terlebih dahulu.

Optimasi $\mathrm{pH}$. Sebanyak 0,5 g alumina dimasukkan ke dalam beaker gelas, kemudian ditambahkan $10 \mathrm{~mL}$ larutan yang $\mathrm{pH}$ nya dibuat bervariasi yaitu $\mathrm{pH} 1-10\left(\mathrm{pH}\right.$ larutan diatur dengan menambahkan $\mathrm{HNO}_{3} 1 \mathrm{M}$ atau $\mathrm{NH}_{4} \mathrm{OH} 1 \mathrm{M}$, dan $\mathrm{pH}$ larutan diukur dengan $\mathrm{pH}$ meter), dan direndam selama 24 jam. Alumina tersebut disaring dan dikeringkan dalam suhu kamar, kemudian masing-masing ditambah dengan $10 \mathrm{~mL}$ larutan standar $\mathrm{Cd}^{2+}$ 
0,1 mg/L. Campuran tersebut dibiarkan selama 1 jam kemudian disaring menggunakan kertas saring whatman 40. Selanjutnya, absorbansi hasil filtrat diukur dengan SSA pada panjang gelombang 228,9 nm. Dari hasil pengukuran diperoleh, $\mathrm{pH}$ optimum resin alumina adalah pada kondisi jumlah ion $\mathrm{Cd}^{2+}$ dalam filtrat yang terukur paling kecil. Hal ini menunjukkan jumlah ion $\mathrm{Cd}^{2+}$ yang terserap di dalam alumina paling besar (optimal).

Penentuan Jenis Eluen. Sebanyak 0,5 g alumina yang telah diaktivasi dengan larutan pengaktivasi pada $\mathrm{pH}$ optimum dimasukkan ke dalam beaker gelas, ditambahkan $10 \mathrm{~mL}$ larutan $\mathrm{Cd}^{2+} 0,1 \mathrm{mg} / \mathrm{L}$, diaduk dan direndam selama 1 jam kemudian disaring. Residu yang dihasilkan ditambahkan dengan masing-masing $10 \mathrm{~mL}$ larutan $\mathrm{HCl}, \mathrm{HNO}_{3}, \mathrm{H}_{3} \mathrm{BO}_{3}, \mathrm{CH}_{3} \mathrm{COOH}$, dengan konsentrasi yang sama sebesar $1 \mathrm{M}$, diaduk dan direndam selama 30 menit kemudian disaring. Filtrat yang dihasilkan diukur absorbansinya dengan SSA pada panjang gelombang 228,9 $\mathrm{nm}$. Dari hasil pengukuran diperoleh, jenis eluen optimum adalah filtrat yang menghasilkan jumlah ion $\mathrm{Cd}^{2+}$ yang terukur lebih besar.

Penentuan Kapasitas Alumina. Sebanyak $1 \mathrm{~g}$ alumina yang telah diaktivasi dengan larutan pengaktivasi pada $\mathrm{pH}$ optimal dimasukkan ke dalam beaker gelas, ditambahkan $10 \mathrm{~mL}$ larutan $\mathrm{Cd}^{2+}$ dengan variasi konsentrasi 0,$05 ; 0,1 ; 0,2 ; 0,5 ; 0,8 ; 1 ; 2 ; 4 ; 8 ; 10 \mathrm{mg} / \mathrm{L}$ kemudian diaduk dan direndam selama 1 jam, lalu disaring. Residu yang dihasilkan ditambahkan dengan masing-masing $10 \mathrm{~mL}$ larutan $\mathrm{HNO}_{3} 1 \mathrm{M}$, diaduk dan direndam selama 30 menit kemudian disaring. Filtrat yang dihasilkan diukur absorbansinya dengan SSA pada panjang gelombang $228,9 \mathrm{~nm}$.

\section{Optimasi Tahapan Prakonsentrasi}

Pembuatan Kolom. Kolom berdiameter $1 \mathrm{~cm}$ dan tinggi $15 \mathrm{~cm}$ diisi dengan $5 \mathrm{~g}$ alumina yang telah diaktivasi pada $\mathrm{pH}$ optimal. Kolom tersebut disangga dengan statif yang terdapat pada tiang (Panggabean et al., 2015).

Optimasi Konsentrasi Eluen. Sebanyak $10 \mathrm{~mL}$ larutan $\mathrm{Cd}^{2+} 0,1 \mathrm{mg} / \mathrm{L}$ dimasukkan ke dalam kolom yang telah berisi alumina teraktivasi. Ion $\mathrm{Cd}^{2+}$ yang teretensi selanjutnya dielusi dengan penambahan $10 \mathrm{~mL}$ larutan eluen (eluen yang optimum) dengan variasi konsentrasi 0,$1 ; 0,3 ; 0,5 ; 0,8 ; 1,0 ; 1,5 \mathrm{M}$. Filtrat yang dihasilkan diukur absorbansinya dengan SSA pada panjang gelombang 228,9 $\mathrm{nm}$.

Optimasi Volume Eluen. Ke dalam kolom yang telah berisi alumina teraktivasi, dimasukkan $10 \mathrm{~mL}$ larutan $\mathrm{Cd}^{2+}$ 0,1 mg/L. Ion $\mathrm{Cd}^{2+}$ yang teretensi selanjutnya dielusi dengan penambahan larutan eluen pada konsentrasi optimum dengan variasi volume 1, 2, 4, 6, 8, $10 \mathrm{~mL}$. Filtrat yang dihasilkan diukur absorbansinya dengan SSA pada panjang gelombang $228,9 \mathrm{~nm}$.

Optimasi Volume Sampel. Ke dalam kolom yang telah berisi alumina teraktivasi, dimasukkan larutan $\mathrm{Cd}^{2+}$ 0,1 mg/L dengan variasi volume $1,2,4,6,8,10,15,20 \mathrm{~mL}$. Ion $\mathrm{Cd}^{2+}$ yang teretensi selanjutnya dielusi dengan penambahan larutan eluen pada konsentrasi optimum dan volume optimum. Filtrat yang dihasilkan diukur absorbansinya dengan SSA pada panjang gelombang 228,9 $\mathrm{nm}$.

\section{Uji Kinerja Analitik}

Uji Linieritas. Larutan $\mathrm{Cd}^{2+}$ dengan variasi konsentrasi $1-100 \mu \mathrm{g} / \mathrm{L}$ dengan kondisi optimum dan prosedur yang sama seperti di atas, kemudian diukur absorbansinya dengan SSA pada panjang gelombang 228,9 $\mathrm{nm}$. Dengan memplotkan absorbansi terhadap konsentrasi $\mathrm{Cd}^{2+}$ akan diperoleh persamaan garis regresi.

Uji Akurasi. Larutan CRM Cd( $\left(\mathrm{NO}_{3}\right)_{2} 1000 \mathrm{mg} / \mathrm{L}$ diencerkan menjadi larutan $\mathrm{Cd}^{2+}$ 49,35 $\mu \mathrm{g} / \mathrm{L}$. Larutan $\mathrm{CRM} \mathrm{Cd}^{2+} 49,35 \mu \mathrm{g} / \mathrm{L}$ dengan kondisi optimum dan prosedur yang sama seperti di atas, kemudian diukur absorbansinya dengan SSA pada panjang gelombang 228,9 $\mathrm{nm}$. Percobaan tersebut dilakukan sebanyak masingmasing 7 kali pengulangan.

Uji Presisi. Larutan $\mathrm{Cd}^{2+}$ dengan konsentrasi $40 \mu \mathrm{g} / \mathrm{L}$ dengan kondisi optimum dan prosedur yang sama seperti di atas, kemudian diukur absorbansinya dengan SSA pada panjang gelombang 228,9 nm. Percobaan tersebut dilakukan sebanyak masing-masing 7 kali pengulangan.

Batas Deteksi. Larutan $\mathrm{Cd}^{2+}$ dengan konsentrasi terkecil pada kondisi optimum dan prosedur yang sama seperti di atas kemudian diukur absorbansinya dengan SSA pada panjang gelombang 228,9 nm. Percobaan tersebut dilakukan sebanyak masing-masing 7 kali pengulangan.

\section{Determinasi Sampel}

Dipersiapkan larutan sampel pupuk NPK yang diperoleh dari PT. Pupuk Kalimantan Timur. Sebanyak 4,8054 g sampel ditimbang dan didestruksi pada furnace dengan suhu $800{ }^{\circ} \mathrm{C}$. Hasil destruksi dilarutkan dalam 
$100 \mathrm{~mL}$ aquabides, dan selanjutnya dilakukan tahapan prakonsentrasi berdasarkan kondisi optimum yang telah diperoleh sebelumnya. Absorbansi eluat yang diperoleh diukur absorbansinya dengan SSA pada panjang gelombang 228,9 nm. Konsentrasi ion Cd dalam sampel dapat diketahui dengan menggunakan persamaan regresi yang diperoleh setelah tahapan prakonsentrasi.

\section{Uji Recovery}

Untuk menguji kemampuan metode dalam menganalisis suatu analit yang terdapat dalam suatu sampel dengan matriks yang komplek, dilakukan dengan uji perolehan kembali (recovery) (Panggabean et al., 2019). Pada tahapan ini, 10 mL larutan CRM Cd 4,935 $\mu \mathrm{g} / \mathrm{L}$ ditambahkan ke dalam $990 \mathrm{~mL}$ larutan sampel, kemudian dialirkan ke dalam kolom dengan tahapan yang sama pada tahapan prakonsentrasi. Absorbansi eluatnya diukur dengan SSA pada panjang gelombang $228,9 \mathrm{~nm}$.

\section{Estimasi Ketidakpastian Metode}

Ketidakpastian menunjukkan nilai dispersi dari setiap tahapan dalam proses pengujian yang dicantumkan dalam nilai ukur yang memberikan rentang terpusat, dimana dalam rentang tersebutlah nilai benar berada. Evaluasi ketidakpastian pengukuran dilakukan secara statistik atau non statistik berdasarkan nilai-nilai yang tersedia seperti sertifikat hasil kalibrasi, data pengukuran sebelumnya, spesifikasi pabrik dan data yang diperoleh dari buku atau literatur (Ellison and Williams, 2012).

Estimasi ketidakpastian prakonsentrasi $\mathrm{Cd}$ ditentukan melalui beberapa tahap. Pada tahap pertama dilakukan pembuatan formula perhitungan yang digunakan untuk menghitung konsentrasi Cd dalam sampel. Tahap kedua merupakan identifikasi seluruh komponen penyumbang ketidakpastian dalam seluruh tahapan metode mulai dari penimbangan sampel, pelarutan sampel, pemipetan sampel, penambahan eluen, pembuatan larutan standar, pengujian dengan SSA hingga presisi metode (Ellison and Williams, 2012). Seluruh komponen penyumbang ketidakpastian tersebut dituangkan ke dalam diagram tulang ikan atau fishbone diagram seperti pada Gambar 1.

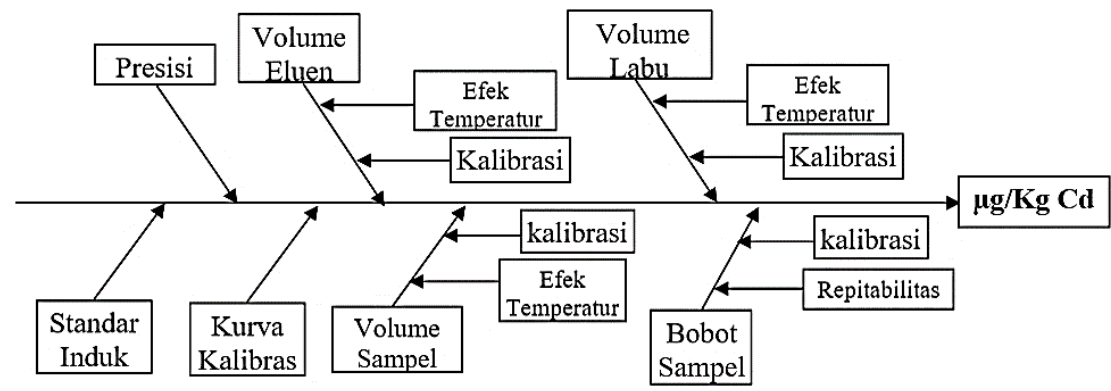

Gambar 1. Sumber ketidakpastian metode prakonsentrasi Cd.

Tahapan ketiga merupakan perhitungan nilai ketidakpastian baku dari tiap sumber ketidakpastian yang telah diidentifikasi, yang berasal dari nilai ketidakpastian pada sertifikat kalibrasi alat, sertifikat larutan standar, perbedaan temperatur ruang laboratorium saat pengujian dan saat kalibrasi alat serta presisi. Selanjutnya dilakukan klasifikasi komponen ketidakpastian tipe A atau tipe B, kemudian perhitungan ketidakpastian gabungan dan dilanjutkan dengan perhitungan ketidakpastian diperluas dengan $\mathrm{k}=2$ dan tingkat kepercayaan sebesar $95 \%$.

\section{HASIL DAN PEMBAHASAN}

\section{Aktivasi Alumina}

Optimasi $\mathrm{pH}$. Tahapan penelitian ini dilakukan dengan metode batch, bertujuan untuk memperoleh $\mathrm{pH}$ optimum penyerapan ion $\mathrm{Cd}^{2+}$ yang paling besar menggunakan alumina teraktivasi. Hasil pengukuran dapat dilihat pada Gambar 2. Hasil penelitian menunjukkan bahwa larutan filtrat pada $\mathrm{pH} 8$ dan 9, tidak mengandung ion $\mathrm{Cd}^{2+}$, sehingga $\mathrm{pH} 8$ dipilih sebagai $\mathrm{pH}$ optimum. Pada $\mathrm{pH} 8$ tersebut, ion $\mathrm{Cd}^{2+}$ dapat terserap secara optimal. Sifat permukaan alumina sangat bergantung pada kondisi $\mathrm{pH}$. Pada $\mathrm{pH}>7$ permukaan alumina menjadi bermuatan negatif karena deprotonasi, sehingga adsorpsi terhadap ion positif menjadi meningkat (Banerjee et al., 2016). 


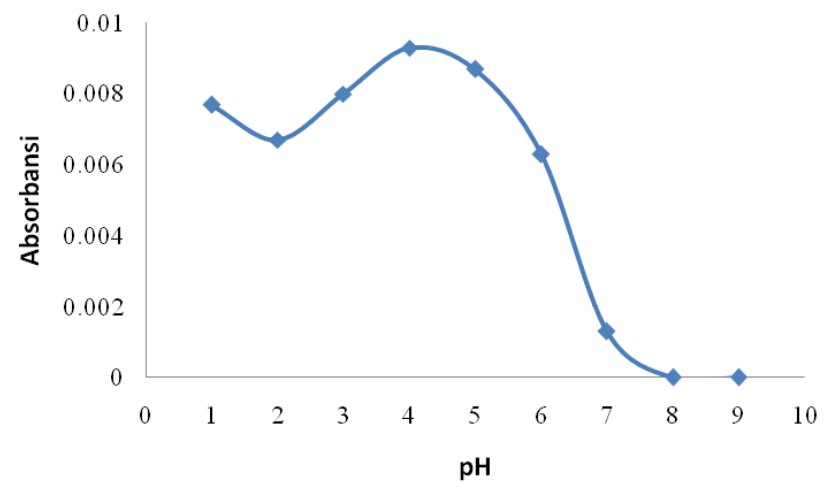

Gambar 2. Optimasi pH alumina.

Penentuan Jenis Eluen. Pada tahapan ini digunakan beberapa jenis eluen yaitu $\mathrm{HCl}, \mathrm{HNO}_{3}, \mathrm{CH}_{3} \mathrm{COOH}$, dan $\mathrm{H}_{3} \mathrm{BO}_{3}$, dengan konsentrasi yang sama sebesar $1 \mathrm{M}$. Ion $\mathrm{H}^{+}$dari eluen asam yang digunakan, akan melepaskan ion $\mathrm{Cd}^{2+}$ yang terikat pada alumina (Amran et al., 2011). Hasil penelitian (Gambar 3) menunjukkan eluen terbaik untuk melepaskan ion $\mathrm{Cd}^{2+}$ adalah $\mathrm{HNO}_{3}$. Selain karena sifat asamnya yang kuat dalam melarutkan logam, $\mathrm{HNO}_{3}$ juga merupakan pelarut logam terbaik dalam pengujian dengan SSA.

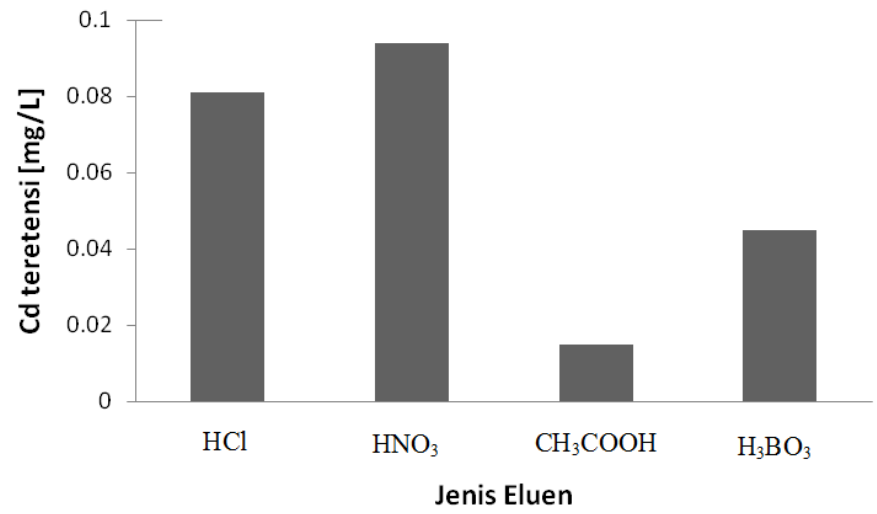

Gambar 3. Penentuan jenis eluen.

Penentuan Kapasitas Alumina. Kapasitas retensi adalah ukuran kemampuan alumina tersebut untuk meretensi ion Cd(II) (Amran et al., 2011). Semakin banyak jumlah ion logam Cd(II) yang diserap, semakin besar kapasitas retensinya. Analisis kapasitas retensi dapat dilakukan dengan metode batch, hasil pengukuran dapat dilihat pada Gambar 4.

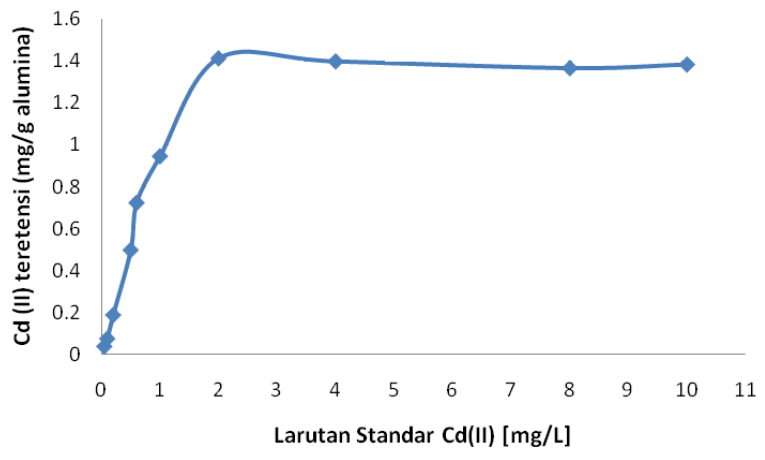

Gambar 4. Penentuan kapasitas alumina.

Pada konsentrasi $\mathrm{Cd}(\mathrm{II})$ 0,05 hingga $2 \mathrm{mg} / \mathrm{L}$, jumlah ion $\mathrm{Cd}^{2+}$ yang terelusi dari alumina masih mengalami kenaikan, sedangkan pada konsentrasi lebih besar dari $2 \mathrm{mg} / \mathrm{L}$ jumlah $\mathrm{Cd}$ terelusi cenderung konstan. Hal ini berarti pada konsentrasi tersebut, semua ion $\mathrm{Cd}(\mathrm{II})$ terabsorpsi oleh alumina teraktivasi. Pada penyerapan dengan konsentrasi larutan $\mathrm{Cd}^{2+} 2 \mathrm{mg} / \mathrm{L}$ diperoleh konsentrasi $\mathrm{Cd}$ yang terelusi adalah $1,4113 \mathrm{mg} / \mathrm{L}$ atau setara dengan 
$1,4113 \mathrm{mg}$ Cd. Angka ini menunjukkan, bahwa untuk setiap $1 \mathrm{~g}$ alumina dapat menyerap maksimal 1,4113 mg $\mathrm{Cd}$, sehingga kapasitas alumina dalam mengikat $\mathrm{Cd}^{2+}$ adalah $1,4113 \mathrm{mg} \mathrm{Cd}^{2+} / \mathrm{g}^{2}$ lumina.

\section{Optimasi Tahapan Prakonsentrasi}

Optimasi Konsentrasi Eluen. Optimasi konsentrasi eluen dilakukan dengan metode kolom. Eluen dalam penelitian ini berperan dalam melepaskan $\mathrm{Cd}^{2+}$ yang telah terikat pada alumina. Variasi konsentrasi $\mathrm{HNO}_{3}$ dilakukan untuk mendapatkan konsentrasi yang tepat untuk dijadikan eluen dalam melepaskan $\mathrm{Cd}^{2+}$ yang telah terikat dengan alumina secara optimal dan juga diharapkan konsentrasi tersebut tidak mengganggu kinerja pengukuran dan merusak material resin yang berada dalam kolom (Panggabean et al., 2014).

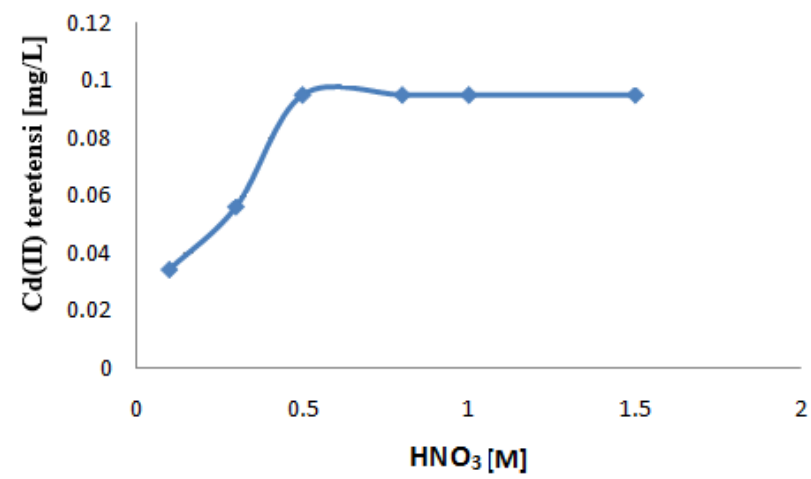

Gambar 5. Optimasi konsentrasi eluen $\mathrm{HNO}_{3}$.

Hasil penelitian pada Gambar 5 menunjukkan bahwa pada penggunaan eluen $\mathrm{HNO}_{3}$ lebih kecil dari 0,3 $\mathrm{M}$, belum dapat melepaskan semua ion $\mathrm{Cd}^{2+}$ yang terikat pada alumina teraktivasi. Nilai absorbansi filtrat untuk konsentrasi eluen $\mathrm{HNO}_{3}$ lebih besar dari $0,5 \mathrm{M}(0,5-1,5 \mathrm{M})$, menunjukkan nilai absorbansi yang diperoleh relatif sama. Oleh karena itu, dalam penelitian ini konsentrasi eluen $\mathrm{HNO}_{3}$ optimum adalah 0,5 M.

Optimasi Volume Eluen. Variasi konsentrasi eluen pada tahapan penelitian ini digunakan pada kondisi yang sama seperti pada penentuan konsentrasi optimum eluen.

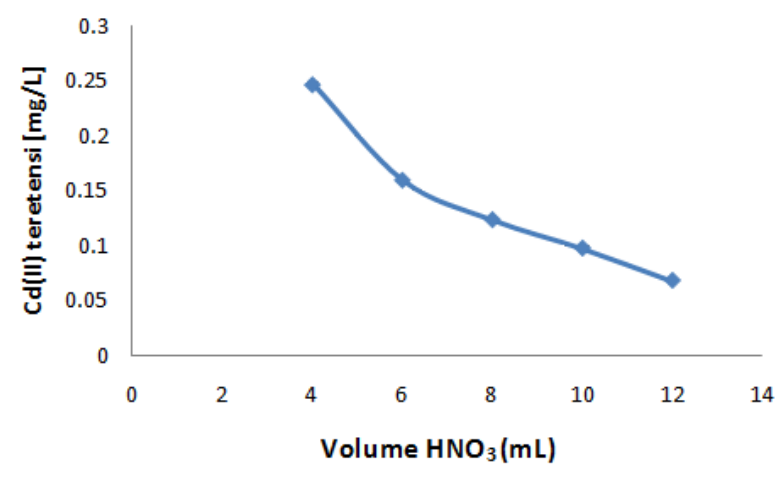

Gambar 6. Optimasi volume eluen $\mathrm{HNO}_{3}$.

Pada tahapan ini, sebanyak $10 \mathrm{ml}$ larutan $\mathrm{Cd}^{2+} 0,1 \mathrm{mg} / \mathrm{L}$ dilewatkan dari kolom yang berisi alumina teraktivasi. Ketika dielusi dengan eluen $\mathrm{HNO}_{3} 0,5 \mathrm{M}$ pada volume $4 \mathrm{~mL}$, diperoleh konsentrasi $\mathrm{Cd}$ (II) yang terdapat pada filtrat menjadi $0,1 \mathrm{mg} / \mathrm{L}$ dalam volume $4 \mathrm{~mL}$ atau $0,25 \mathrm{mg} / \mathrm{L}$, yang ditunjukkan dalam Gambar 6 . Hal ini menunjukkan terjadi peningkatan konsentrasi Cd(II) hasil prakonsentrasi sebesar 2,5 kali dari konsentrasi $\mathrm{Cd}$ (II) sampel awal yang digunakan. Untuk volume eluen $\mathrm{HNO}_{3} 0,5 \mathrm{M}$ lebih dari $4 \mathrm{~mL}$, konsentrasi $\mathrm{Cd}$ (II) pada filtrat mengalami penurunan. Hal ini disebabkan terjadinya pengenceran terhadap jumlah $\mathrm{Cd}(\mathrm{II})$ yang dilepaskan dari alumina teraktivasi dengan bertambahnya volume eluen. Dari tahapan optimasi volume eluen disimpulkan bahwa volume $\mathrm{HNO}_{3} 0,5 \mathrm{M}$ optimum adalah $4 \mathrm{~mL}$. 


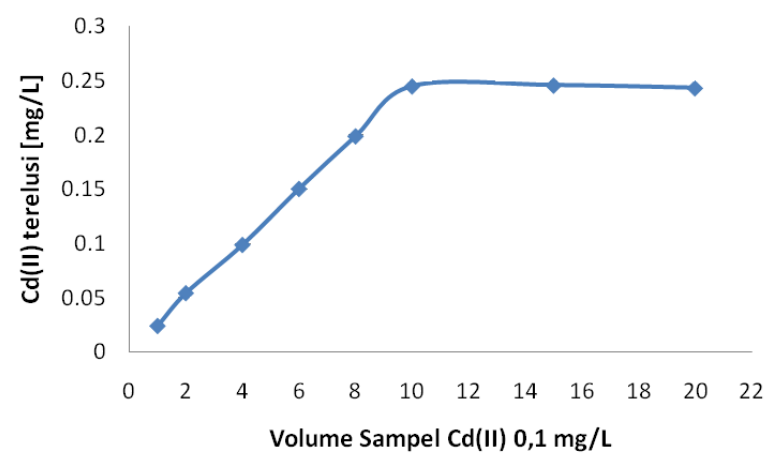

Gambar 7. Penentuan volume sampel.

Penentuan Volume Sampel. Penentuan volume sampel dilakukan untuk mengetahui volume optimum dari $\mathrm{Cd}(\mathrm{II})$ yang mampu ditangkap oleh alumina. Penelitian menunjukkan bahwa terjadi peningkatan konsentrasi $\mathrm{Cd}(\mathrm{II})$ yang terelusi seiring dengan peningkatan volume sampel antara $1-10 \mathrm{~mL}$. Pada volume sampel $10-20 \mathrm{~mL}$, konsentrasi Cd yang terelusi konstan. Berdasarkan Gambar 7 dapat diketahui bahwa volume ion $\mathrm{Cd}(\mathrm{II})$ optimum adalah $10 \mathrm{~mL}$. Pada volume tersebut alumina sudah berada dititik maksimal dalam menangkap $\mathrm{Cd}(\mathrm{II})$.

\section{Penentuan Kinerja Analitik}

Uji Linieritas. Uji linieritas bertujuan untuk mengetahui kemampuan metode memperoleh hasil uji berbanding lurus dengan konsentrasi analit dalam suatu rentang yang ditetapkan (Kantasubrata, 2005; Miller and Miller, 2005). Pada penelitian ini uji linieritas dilakukan dengan memplotkan hasil pengukuran absorbansi dari larutan seri standar $\mathrm{Cd}(\mathrm{II})$ dengan konsentrasi larutan standar yang dibuat bervariasi. Data hasil uji linieritas sebelum dan setelah prakonsentrasi disajikan pada Gambar 8.

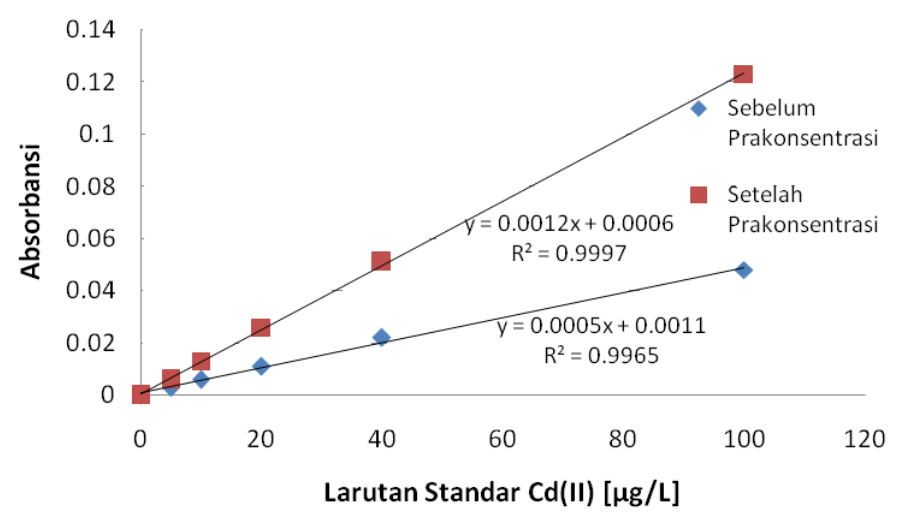

Gambar 8. Pembuatan kurva kalibrasi larutan standar Cd(II).

Hasil penelitian pada Gambar 8 menunjukkan terdapat perbedaan nilai absorbansi pada larutan standar $\mathrm{Cd}(\mathrm{II})$ sebelum dan setelah prakonsentrasi. Hal ini menunjukkan tahapan prakonsentrasi dan kinerja yang dikembangkan telah berhasil dengan baik. Koefisien determinasi $\left(\mathrm{R}^{2}\right)$ sebelum prakonsentrasi adalah 0,9965 dengan persamaan garis regresi $y=0,0005 x+0,0011$. Nilai $R^{2}$ setelah prakonsentrasi adalah 0,9997 dengan persamaan garis regresi $\mathrm{y}=0,0012 \mathrm{x}+0,0006$. Kriteria nilai koefisien korelasi yang dipersyaratkan adalah $\mathrm{R}^{2} \geq 0,990$ (Riyanto, 2014). Persamaan regresi menunjukkan terjadinya peningkatan gradien antara kurva kalibrasi sebelum dan setelah prakonsentrasi sebesar 2,5 kali.

Uji Akurasi. Uji akurasi bertujuan untuk mengetahui derajat kesamaan antara hasil analisis dengan nilai sesungguhnya dari sampel (Riyanto, 2014). Dalam penelitian ini uji akurasi dilakukan menggunakan CRM (Certified Reference Material) dari E'Merck dengan konsentrasi $\mathrm{Cd}^{2+} 987 \mathrm{mg} / \mathrm{L}$ yang diencerkan menjadi $49,35 \mu \mathrm{g} / \mathrm{L}$. Hasil uji akurasi menunjukkan nilai akurasi berada pada rentang 97,26 - 100,64\%, seperti yang ditunjukkan dalam Tabel 1. Nilai tersebut memenuhi persyaratan akurasi yang ditetapkan untuk konsentrasi 
standar $\mu \mathrm{g} / \mathrm{L}$, yaitu pada rentang 75 - 125\% (Miller and Miller, 2005), sehingga metode prakonsentrasi Cd(II) ini dapat disimpulkan memiliki akurasi yang baik.

Tabel 1. Uji akurasi dengan CRM Cd (E’Merck).

\begin{tabular}{cccc}
\hline Pengulangan & Absorbansi & Mg/L Cd CRM & \% Akurasi \\
\hline 1 & 0,031 & 49,67 & 100,64 \\
2 & 0,032 & 51,33 & 104,02 \\
3 & 0,030 & 48,00 & 97,26 \\
4 & 0,032 & 51,33 & 104,02 \\
5 & 0,030 & 48,00 & 97,26 \\
6 & 0,031 & 49,67 & 100,64 \\
7 & 0,031 & 49,67 & 100,64 \\
\hline
\end{tabular}

Uji Presisi. Uji presisi bertujuan untuk mengetahui derajat kesamaan pengukuran yang diulang beberapa kali dalam keadaan yang serba sama (Harmita, 2004; Taufiq et al., 2020). Uji presisi dilakukan terhadap larutan standar $\mathrm{Cd}^{2+} 40 \mu \mathrm{g} / \mathrm{L}$ sebanyak 7 kali pengulangan dan diperoleh nilai RSD 4,03\%. Nilai \% RSD yang dihasilkan memenuhi persyaratan yaitu nilai \% RSD < 2/3\% CV Horwitz $(4,03<17,32)$, seperti dapat dilihat pada Tabel 2. Hal ini menunjukkan bahwa metode ini memiliki keterulangan yang baik.

Tabel 2. Uji presisi.

\begin{tabular}{|c|c|c|}
\hline Pengulangan & Absorbansi & $\mathrm{Cd}^{2+}[\mu \mathrm{g} / \mathrm{L}]$ \\
\hline 1 & 0,025 & 39,67 \\
\hline 2 & 0,026 & 41,33 \\
\hline 3 & 0,027 & 43,00 \\
\hline 4 & 0,026 & 41,33 \\
\hline 5 & 0,024 & 38,00 \\
\hline 6 & 0,025 & 39,67 \\
\hline 7 & 0,025 & 39,67 \\
\hline \multicolumn{2}{|c|}{ Rata-Rata $(\mu \mathrm{g} / \mathrm{L})$} & 40,38 \\
\hline \multicolumn{2}{|c|}{ Standar Deviasi $(\mu \mathrm{g} / \mathrm{L})$} & 1,6265 \\
\hline \multicolumn{2}{|c|}{$\%$ RSD } & 4,03 \\
\hline \multicolumn{2}{|c|}{$2 / 3 \%$ CV Horwitz } & 17,32 \\
\hline
\end{tabular}

Uji Batas Deteksi. Batas deteksi menunjukkan kemampuan sekaligus keterbatasan laboratorium dalam menerapkan suatu metode pengujian tertentu pada kadar rendah (Miller and Miller, 2005). Pada penelitian ini batas deteksi (limit of detection, LOD) yang ditentukan adalah LOD instrumen, dan ditetapkan menggunakan larutan standar $\mathrm{Cd}^{2+}$ dengan konsentrasi terkecil. Dari hasil penelitian yang ditunjukkan dalam Tabel 3, menunjukkan bahwa teknik prakonsentrasi yang dikembangkan memiliki nilai LOD 2,7997 $\mu \mathrm{g} / \mathrm{L}$.

Tabel 3. Uji limit deteksi metode.

\begin{tabular}{ccc}
\hline Pengulangan & Absorbansi & $\boldsymbol{\mu g} / \mathbf{L ~} \mathbf{C d}^{\mathbf{2 +}}$ \\
\hline 1 & 0,002 & 1,33 \\
2 & 0,003 & 3,00 \\
3 & 0,002 & 1,33 \\
4 & 0,003 & 3,00 \\
5 & 0,003 & 3,00 \\
6 & 0,002 & 1,33 \\
7 & 0,003 & 3,00 \\
\hline \multicolumn{3}{c}{ Limit Deteksi Metode $(\mu \mathrm{g} / \mathrm{L})$} \\
\hline Limit Kuantitasi $(\mu \mathrm{g} / \mathrm{L})$ \\
\hline
\end{tabular}




\section{Pengukuran Cd dalam Pupuk NPK}

Sampel yang digunakan dalam penelitian ini adalah pupuk NPK yang diperoleh dari PT. Pupuk Kalimantan Timur. Konsentrasi ion Cd (II) dalam sampel dapat diketahui dengan menggunakan persamaan regresi setelah tahapan prakonsentrasi, seperti pada Tabel 4.

Tabel 4. Pengujian sampel pupuk NPK.

\begin{tabular}{cccc}
\hline \multirow{2}{*}{ Pengulangan } & \multicolumn{2}{c}{ Absorbansi } & \multirow{2}{*}{ Cd $[\boldsymbol{\mu g} / \mathbf{L}]$} \\
\cline { 2 - 3 } & Sebelum Prakonsentrasi & Setelah Prakonsentrasi & 6,1667 \\
1 & 0,000 & 0,008 & 6,1667 \\
3 & 0,000 & 0,008 & 5,3333 \\
4 & 0,000 & 0,007 & 6,1667 \\
5 & 0,000 & 0,008 & 6,1667 \\
6 & 0,000 & 0,008 & 5,3333 \\
7 & 0,000 & 0,007 & 6,1667 \\
\hline \multicolumn{2}{r}{} \\
\hline
\end{tabular}

Berdasarkan hasil pengukuran (Tabel 4), jumlah Cd(II) dalam sampel pupuk NPK apabila dianalisis langsung dengan SSA (sebelum prakonsentrasi) tidak terdeteksi. Setelah melewati tahapan prakonsentrasi diperoleh jumlah $\mathrm{Cd}^{2+}$ sebesar 5,9286 $\mu \mathrm{g} / \mathrm{L}$ atau setara dengan 123,3731 $\mu \mathrm{g} / \mathrm{kg}$. Angka ini adalah konversi dari hasil pengukuran $\mathrm{Cd}^{2+}$ dalam sampel 5,9286 $\mu \mathrm{g} / \mathrm{L}(\mathrm{b} / \mathrm{v})$ dengan berat sampel awal 4,8054 g yang didestruksi dan kemudian dilarutkan dalam $100 \mathrm{~mL}$ aquabides. Setelah dihitung, memberikan hasil yaitu 123,3731 $\mu \mathrm{g} / \mathrm{kg}(\mathrm{b} / \mathrm{b})$.

Uji Recovery. Hasil uji perolehan kembali (recovery) menunjukkan bahwa \% recovery teknik prakonsentrasi ini berkisar 91,67 - 103,49\%, seperti yang ditunjukkan dalam Tabel 5. Nilai tersebut memenuhi persyaratan, dimana batasan \% recovery untuk kadar $\mu \mathrm{g} / \mathrm{L}$ (ppb) adalah $70-125 \%$ (Miller and Miller, 2005), sehingga dapat disimpulkan bahwa akurasi teknik prakonsentrasi yang dikembangkan ini baik dan adanya matriks sampel tidak mempengaruhi penentuan konsentrasi ion $\mathrm{Cd}(\mathrm{II})$.

Tabel 5. Uji Recovery.

\begin{tabular}{cccc}
\hline Pengulangan & $\begin{array}{c}\text { Absorbansi } \\
\text { (sampel + standar) }\end{array}$ & $\begin{array}{c}\text { Cd }[\boldsymbol{\mu} \text { g/L] } \\
\text { (Sampel + Standar) }\end{array}$ & \% Recovery \\
\hline 1 & 0,062 & 51,1667 & 91,67 \\
2 & 0,065 & 53,6667 & 96,73 \\
3 & 0,064 & 52,8333 & 95,05 \\
4 & 0,067 & 55,3333 & 100,11 \\
5 & 0,062 & 51,1667 & 91,67 \\
6 & 0,069 & 51,1667 & 103,49 \\
7 & 0,063 & 52,0000 & 93,36 \\
\hline
\end{tabular}

\section{Estimasi Ketidakpastian Metode}

Pada teknik prakonsentrasi Cd(II) ini, sumber ketidakpastian berasal dari efek sistematik dan efek acak. Sumber ketidakpastian yang berasal dari efek sistematik bersumber dari volume sampel, volume eluen, dan pembacaan alat dan penimbangan sampel sedangkan sumber ketidakpastian yang berasal dari efek acak bersumber dari keterulangan atau presisi metode (Ellison and Williams, 2012). Sumber-sumber ketidakpastian tersebut kemudian dicantumkan pada diagram tulang ikan (fishbone diagram) yang disajikan pada Gambar 1 sebelumnya.

Ketidakpastian gabungan diperoleh dengan menggabungkan seluruh nilai ketidakpastian dari seluruh komponen penyumbang ketidakpastian dalam penelitian ini. Berdasarkan perhitungan penggabungan sumbersumber ketidakpastian diperoleh nilai ketidakpastian diperluas (U) dengan tingkat kepercayaan 95\% $(\mathrm{k}=2)$ adalah $17,4722 \mu \mathrm{g} / \mathrm{kg}$. Konsentrasi Cd dalam pupuk NPK metode prakonsentrasi ini dapat dilaporkan $123,3731 \pm 17,4722 \mu \mathrm{g} / \mathrm{kg}$ dengan $\%$ ketidakpastian adalah $14,16 \%$. 


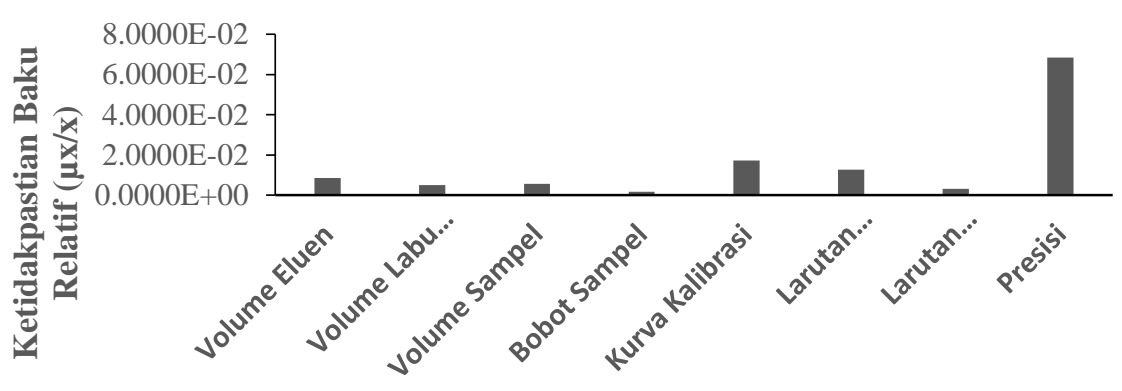

Sumber Ketidakpastian

Gambar 9. Komponen penyumbang ketidakpastian.

Berdasarkan Gambar 9, data perhitungan ketidakpastian dapat dilihat penyumbang ketidakpastian terbesar berasal dari presisi metode. Hal ini disebabkan karena beberapa faktor yang turut mempengaruhi hasil analisis misalnya kondisi lingkungan (temperatur), instrumen dan analis. Pada presisi metode, analis dimasukkan sebagai salah satu faktor yang mempengaruhi analisis, karena hasil pengukuran sangat dipengaruhi oleh kemampuan dan keterampilan seorang analis yang melakukan pengukuran. Setiap analis mempunyai kesalahan pengukuran yaitu kesalahan mutlak, yang sangat menentukan akurasi dan presisi hasil pengukuran. Selain itu, kecilnya konsentrasi analit dalam sampel menyebabkan kecil pula sinyal yang dihasilkan oleh SSA. Perbedaan sedikit saja sinyal yang dihasilkan oleh SSA dalam pengerjaan presisi dapat menyebabkan deviasi yang besar. Standar deviasi yang besar 8,4618 berbanding terbalik dengan konsentrasi analit dalam sampel yang sangat kecil yaitu $123,3731 \mu \mathrm{g} / \mathrm{kg}$, sehingga menyebabkan nilai relative standard deviation (RSD) dan nilai ketidakpastian presisi besar yaitu 6,86\%. Penyumbang ketidakpastian kedua adalah kurva kalibrasi diikuti oleh larutan standar tipe B, volume eluen, volume labu takar, larutan standar tipe A, dan bobot sampel.

\section{KESIMPULAN}

Metode prakonsentrasi ion Cd(II) dalam sampel pupuk NPK dapat dilakukan menggunakan alumina teraktivasi sebagai bahan pengisi kolom dengan kondisi optimal tahapan prakonsentrasi pada $\mathrm{pH} 8$, menggunakan eluen $\mathrm{HNO}_{3}$ 0,5 M sebanyak $4 \mathrm{~mL}$ dengan volume sampel sebanyak $10 \mathrm{~mL}$. Kapasitas alumina adalah 1,4113 mg Cd(II)/g alumina. Kinerja analitik yang diperoleh sangat baik ditunjukkan dengan nilai akurasi $97,26-104,02 \%$, persentase perolehan kembali 91,67 - 103,49\%, persentase RSD 4,03\%, limit deteksi $2,7997 \mu \mathrm{g} / \mathrm{L}$ dan estimasi ketidakpastian $14,16 \%$.

\section{UCAPAN TERIMA KASIH}

Terima kasih kepada Pimpinan dan Staf PT. Pupuk Kalimantan Timur, Bontang untuk fasilitas laboratorium dan sampel yang disediakan dalam pelaksanaan penelitian ini.

\section{DAFTAR PUSTAKA}

Amran, M.B., Panggabean, A.S., Sulaeman, A., and Rusnadi., 2011. Preparation of a Chelating Resin and It's Application as a Preconcentration System for Determination of Cadmium in River by Flow Injection Analysis. International Journal of Environmental Research 5(2), 531-536. doi: 10.22059/IJER.2011.337.

Banerjee, S., Dubey, S., Gautam, R.K., and Chattopadhyaya, M., 2016. Adsorption Characteristic of Alumina Nanoparticles for Removal Hazardous Dye, Orange G from Aqueous Solution. Arabian Journal Chemistry 12(8), 5339-5354. doi: 10.1016/j.arabjc.2016.12.016.

Ellison, S.L.R and Williams, A., 2012. EURACHEM/CITAC Guide; Quantifying Uncertainty in Analytical Measurement. $3^{\text {rd }}$ edition, Eurachem; Co-Operation on International Traceability in Analytical Chemistry, Germany.

Gouda, A.A. and Zordok, W.A., 2018. Solid-phase Extraction Method for Preconcentration of Cadmium and Lead in Environmental Samples Using Multiwalled Carbon Nanotubes. Turkish Journal of Chemistry 42, 1018-1031. doi: 10.3906/kim-1711-90.

Han, H., Xu, Y., and Zhang, C., 2011. Determination of Available Cadmium and Lead in Soil by Flame Atomic Absorption Spectromrty after Cloud Point Extraction. Communications in Soil Science and Plant Analysis 42(14), 1739-1751. doi: 10.1080/00103624.2011.584595. 
Harmita, 2004. Petunjuk Pelaksanaan Validasi Metode dan cara Perhitungannya. Majalah Ilmu Kefarmasian 1(3), 117-135. doi: 10.7454/psr.v1i3.3375.

Kantasubrata, J., 2005. Validasi Metode. Pusat Penelitian Kimia LIPI, Bandung.

Koesmawati, T., Moelyo, M., Rizqiani, A., and Tanuwidjaja, S., 2017. Pre-concentration of Pb, Cd, and Ni in River Water Using Back Extraction Method. IOP Conference Series Earth and Environmental Science, 60(1): 012021. doi: 10.1088/1755-1315/60/1/012021.

Mardiani, A., 2008. Pengenalan Proses Bisnis PT. Pupuk Kalimantan Timur. PT. Pupuk Kalimantan Timur, Bontang.

Miller, J.N. and Miller J.C., 2005. Statistics and Chemometrics for Analytical Chemistry. $5^{\text {th }}$ Edition. Pearson Education Limited, England.

Miro, M. and Frenzel, W., 2014. Flow-Through Sorptive Preconcentration with Direct Optosensing at Solid Surfaces for Trace Ion Analysis. Trends in Analytical Chemistry 23(1), 49-53. doi: 10.1016/S01659936(04)00107-4.

Ozdemir, S., 2016. Preconcentration of Cd(II) and Cu(II) by Solid Phase Extraction on Thermophilic Bacillus firmus Loaded Amberlite XAD-4 Prior to their Determination Food Samples by ICP-OES. Journal of Institute of Natural \& Applied Sciences 21(2), 152-166. doi: 10.1007/s13762-020-02845-3.

Panggabean, A.S., Pasaribu, S.P., Bohari, and Nurhasanah., 2014. Preconcentration of Cromium(VI) at Trace Levels Using Acid Alumina Resin with Column Method. Indonesian Journal of Chemistry 14(1), 51 - 56. doi: 10.22146/ijc.21267.

Panggabean, A.S., and Yusuf, B., 2015. Determination of Chromium (VI) By Using Chitosan-1,5-Diphenyl Carbazide Resin Modified at the Preconcentration System with Colomn Method. International Journal of Pharma and Bio Sciences 6(3), 101-111.

Panggabean, A.S., Widyastuti, T., and Hindryawati, N., 2019. Validasi Metode Penentuan Benzena, Toluena dan Xilena pada Sampel Udara dan Tanah Menggunakan Kromatografi Gas. ALCHEMY Jurnal Penelitian Kimia 15(2) 2019, 177-189. doi: 10.20961/alchemy.15.1.25522.177-189.

Pirdaus, P., Rahman, M., Rinawati, Juliasih, N.G., Pratama, D., and Kiswandono, A.A., 2018. Verifikasi Metode Analisis Logam $\mathrm{Pb}, \mathrm{Cd}, \mathrm{Cr}, \mathrm{Cu}, \mathrm{Ni}, \mathrm{Co}, \mathrm{Fe}, \mathrm{Mn}$ dan $\mathrm{Ba}$ pada Air Menggunakan Inductively Coupled Plasma-Optical Emission Spectrometer (ICP-OES). Analit: Analytical and Enviromental Chemistry 3(1), 110. doi: 10.23960/aec.v3.i1.2018.p1-10.

Perkovic, I., Lazic, A., Pernar, N., Roje, V., and Baksic, D., 2017. Forest Soil Poluttion with Heavy Metals (Pb, $\mathrm{Zn}, \mathrm{Cd}$ and $\mathrm{Cu}$ ) in the Area of the "French Mines" on the Medvednica Mountain, Republic of Croatia. Seefor South-East European Forestry 8(1), 31-40. doi: 10.15177/seefor.17-08.

Pourreza, N., Rastegarzadeh, S., and Larki, A., 2014. Simultaneous Preconcentration of Cd(II), Cu(II) and Pb(II) on $\mathrm{Nano}_{-} \mathrm{TiO}_{2}$ Modified with 2-Mercaptobenzothiazole Prior to Flame Atomic Absorption Spectrometric Determinaton. Journal of Industrial and Engineering Chemistry 20(5),2680-2686. doi: 10.1016/j.jiec.2013.10.055.

Riyanto., 2014. Validasi dan Verifikasi Metode Uji. Penerbit Deepublish, Yogyakarta.

SNI., 2012. Pupuk NPK Padat. Badan Standardisasi Nasional, Jakarta.

Sutrisno and Kuntyastuti, H., 2015. Pengelolaan Cemaran Kadmium Pada Lahan Pertanian di Indonesia. Buletin Palawija 13(1), 83-91. doi: 10.21082/bul palawija.v13n1.2015.p83-91.

Suwarsa, S, Buchari, and Panggabean, A.S., 2008. Pengembangan Metode Prakonsentrasi secara Analisis Injeksi Alir untuk Analisis Ion $\mathrm{Cu}^{2+}$ dan $\mathrm{Pb}^{2+}$ dalam Air Aliran Sungai Citarum dan Waduk Saguling. Jurnal Matematika \& Sains 13(3), 84-89.

Taufiq, M., Kiptiyah, K., and Muti'ah, R., 2020, Pengembangan dan Validasi Prosedur Pengukuran Logam Timbal $(\mathrm{Pb})$ dalam Makanan Pendamping Air Susu Ibu Menggunakan Spektroskopi Serapan Atom. ALCHEMY Jurnal Penelitian Kimia 16(1), 25-37. doi: 10.20961/alchemy.16.1.35190.25-37.

Xu, H., Wu, Y., Wang, J., Shang, X., and Jiang, X., 2013. Simultaneous Preconcentration of Cadmium and Lead in Water Samples with Silica Gel and Determination by Flame Atomic Absorption Spectrometry. Journal of Environmental Sciences 25(1), 45-49. doi: 10.1016/S1001-0742(14)60624-0.

Yildiz, D., Kula, I., and Sahin, N., 2013. Preconcentration and Determination of Cd, Zn and Ni by Flame Atomic Absorption Spectrophotometry by Using Microorganism Streptomyces Albus Immobilized on Sepiolite. Eurasian Journal of Analytical Chemistry 8(3), 112-122. 